\title{
Hellenism and Empire: reading Edward Said
}

Article

Accepted Version

Vasunia, P. (2003) Hellenism and Empire: reading Edward Said. Parallax, 9 (4). pp. 88-97. ISSN 1460-700X doi:

https://doi.org/10.1080/1353464032000142390 Available at https://centaur.reading.ac.uk/32331/

It is advisable to refer to the publisher's version if you intend to cite from the work. See Guidance on citing.

To link to this article DOI: http://dx.doi.org/10.1080/1353464032000142390

Publisher: Routledge

All outputs in CentAUR are protected by Intellectual Property Rights law, including copyright law. Copyright and IPR is retained by the creators or other copyright holders. Terms and conditions for use of this material are defined in the End User Agreement.

\section{www.reading.ac.uk/centaur}

\section{CentAUR}

Central Archive at the University of Reading

Reading's research outputs online 


\title{
HELLENISM AND EMPIRE: READING EDWARD SAID
}

\author{
Phiroze Vasunia
}

What can we say about Hellenism and Empire? Not very much, to judge by the attention given to the subject in contemporary scholarship. Although the works of Edward Said, Gayatri Spivak, Homi Bhabha, and others have had some influence on classical studies in the past two decades, the implications of their writings for the study of antiquity in general and Hellenism in particular have not been well appreciated. While some of their claims, and this is especially true of Edward Said, have been adopted in broad terms or as vague generalities by teachers and scholars of antiquity, few classicists or Hellenists have directly engaged this body of work with an eye to the shaping of their discipline. Thus, it is surprising that, despite the recent increased interest in the history of classical scholarship, relatively little consideration has been given to colonial and postcolonial studies, fields which have dealt with the politics of knowledge. Any account of Hellenism and of the reception of the Hellenic past in the modern period remains substantially incomplete without an understanding of European colonialism in the eighteenth, nineteenth, and twentieth centuries. In this essay, I would like to offer some reflections on Said's work and examine its usefulness for the history of Hellenism. We shall explore the challenges posed by his writings and ask where these might contribute to a revaluation of the Greek past and to the evolution of the discursive practices that have surrounded it in the last two hundred years. As we shall see, classical scholarship's evasion of colonialism has far-reaching implications for the understanding of Hellenism today. While Said's work has been used and explored by several scholars of ancient Greece, especially in so far as his work directly mentions ancient history, scholars frequently appear to mention his name only then to forget his larger claims and to 
practise unchanged their scrutiny of antiquity, as if invoking Orientalism were a sufficient gesture in itself or as if the context of modern European colonialism were irrelevant.

No Hellenist reader of Orientalism will have missed the treatment of Aeschylus and Euripides that Said offers in the first chapter of the book. In these remarks, Said traced Orientalism back to the culture of fifth-century Greece. The book's introduction had called for Orientalism to be regarded 'as a Western style for dominating, restructuring, and having authority over the Orient', and it argued that in the late eighteenth century Orientalism came to be 'something more historically and materially defined' and that it was closely linked to European and, later, American imperialism. ${ }^{1}$ Said's return to the Greeks in chapter 1 is an attempt to situate ancient representations of the Orient as the precursors to the post-Enlightenment phenomenon of Orientalism. After noting that the demarcation between the Orient and the West 'already seems bold by the time of the Iliad', he moves on to a consideration of Aeschylus' Persians and Euripides' Bacchae. 'The two aspects of the Orient that set it off from the West in this pair of plays will remain essential motifs of European imaginative geography,' writes Said. 'A line is drawn between the two continents. Europe is powerful and articulate; Asia is defeated and distant.... There is an analogy between Aeschylus's orchestra, which contains the Asiatic world as the playwright conceives it, and the learned envelope of Orientalist scholarship, which also will hold in the vast, amorphous Asiatic sprawl for sometimes sympathetic but always dominating scrutiny.' This is the first essential motif. 'Secondly, there is the motif of the Orient as insinuating danger. Rationality is undermined by Eastern excess, those mysteriously attractive opposites to what seem to be normal values.' ${ }^{\prime 3}$ Thus, Said suggests that modern Orientalism, with all its ideological, military, political, scientific, sociological, and imaginative dimensions, was informed to a significant degree by ancient anxieties. 
In fact, Hellenists have responded to this claim of Said in their writings. Edith Hall argues, in Inventing the Barbarian, itself a book influenced by Said's work, that Aeschylus' Persians 'represents the first unmistakable file in the archive of Orientalism, the discourse by which the European imagination has dominated Asia ever since by conceptualising its inhabitants as defeated, luxurious, emotional, cruel, and always as dangerous'. ${ }^{4}$ Hall's book is clearly made possible by Said's work; indeed, it is unthinkable without it. There are many other examples of scholars who have drawn, to a lesser or greater degree, on this aspect of his book. ${ }^{5}$ It should be said, moreover, that the Greekbarbarian antithesis has been an enduring concern of Hellenists since long before the publication of Orientalism, a concern that dates back at least to Julius Jüthner's Hellenen und Barbaren of 1923 and Walther Kranz's Stasimon of 1933. Some Hellenists have even claimed that Said's book was anticipated in large part by Arnaldo Momigliano's Alien Wisdom, which was first published in 1975 but based on lectures delivered a few years earlier. Whatever the merits of this claim, we can see that Said gave the issue of Greeks and barbarians an interpretative framework and depth that it had hitherto lacked, and assuredly no Hellenist treated the issue with the same commanding sweep and range of texts and materials as Said did in Orientalism. ${ }^{6}$

Underling the more recent work on ancient Orientalism is, however, a disconcerting assumption that is worth a brief mention. To trace the roots of Orientalism back to Greece is to bestow on Hellenic antiquity a sanctity of origin or a founding point of reference which, in the light of the history of European thought, has come to appear extremely problematic. Said himself has been much chastised for presenting literary history in the form of a unified and continuous grand narrative extending from antiquity to the present day. In fact, this criticism misses the point since Said was keen to suggest in Orientalism that the authoritative nature of the unbroken European cultural tradition was founded on massive denial and violence. The idea that a post-Enlightenment discursive formation could be traced back in any unmediated sense to ancient Greece was 
a self-validating European construct and fantasy. Moreover, as Said showed by example, every discursive tradition has a history and a politics, and it cannot simply emerge out of a vacuum. While many Hellenists have maintained a scrupulous concern for methodology and for the historical location of their work, it needs to be said that some, whether deliberately or not, have continued to practise a scholarship in which ancient Greece maintains its delusive position of privilege. Scholars of antiquity who have attempted critiques of Orientalism, thus, have regularly also reaffirmed the sovereign authority of the very tradition that they seek to call into question.

If Said's work presents the East-West distinction as the problematic and phantasmatic retrojection of a modern European tradition, this is a distinction that Hellenists have perpetuated implicitly or explicitly in their writings. Thus, despite the scholarship of Martin Bernal, Walter Burkert, and Martin West, among others, the interconnectedness of Greece with Egypt and the Near East is often ignored or marginalized. ${ }^{7}$ Sometimes, this neglect appears as a disregard for non-Greek sources, or inversely, as an unquestioning acceptance of Greek sources that pertain to the non-Greek world; at other times, such neglect blinds modern readers to the socio-political investment made in the texts by ancient Greeks. In this sense, the scholarly failure to situate Greek culture within the much larger context of the eastern Mediterranean and West Asia finds a parallel in European Philhellenism of the eighteenth and nineteenth centuries. This Philhellenism, which led to the aggressive promotion of Altertumswissenschaft in Germany and Classics in England, was premised on the belief in Greece as a pure ideal uncorrupted by foreign traits, an ideal which itself was subject to considerable debate and in turn compelled many Philhellenists to reaffirm the Greeks' purity. As Said's work implies, Philhellenism is coincident with Orientalism to the extent that it succeeds in detaching Greece from the Orient, despite all the evidence to the contrary. On the other hand, as Stathis Gourgouris, following Said, reminds us, Philhellenism is 'an Orientalism in the most profound sense' because it 'engages in the 
like activity of representing the other culture, which in effect means replacing the other culture with those self-generated, projected images of the otherness that Western culture needs to see itself in'. ${ }^{8}$ Unlike Egypt and India, Greece has not been colonized by Europe, but like Egypt and India, Greece has been appropriated by a European project of discursive control and self-representation. Significantly, then, Said's work suggests that Philhellenism and Orientalism were mutually reinforcing ideologies, but this is the less surprising since European imperialism and colonialism served as the context for both phenomena.

Before I turn to the subject of European colonialism more directly, however, I would like to reflect for a moment on the juxtaposition of Hellenism and Orientalism, especially since the very same juxtaposition is made by one of the most fervent critics of Edward Said's Orientalism. In an essay entitled 'The Question of Orientalism', Bernard Lewis sets out an imaginary scenario as a prelude to his denunciation of Said's book. Imagine a situation in which a group of patriots and radicals from Greece decides that the profession of classical studies is insulting to the great heritage of Hellas and that those engaged in these studies, known as classicists, are the latest manifestation of a deep evil conspiracy, incubated for centuries, hatched in Western Europe, fledged in America, the purpose of which is to denigrate the Greek achievement and subjugate the Greek lands and peoples. In this perspective, the entire European tradition of classical studies-largely the creation of French romantics, British colonial governors (of Cyprus, of course), and poets, professors, and proconsuls from both countries - is a long-standing insult to the honor and integrity of Hellas and a threat to its future. The poison has spread from Europe to the United States, where the teaching of Greek history, language, and literature in the universities is dominated by the evil race of classicists - men and women who are not of Greek origin, who have no sympathy for Greek causes, and 
who, under the false mask of dispassionate scholarship, strive to keep the Greek people in a state of permanent subordination. ${ }^{9}$

In this deliberately fantastic situation, Lewis continues, only Greeks and a few sympathetic non-Greeks will be permitted to write and teach about Greece from antiquity to the present time; non-Greeks who do not hold to the appropriate criteria or ideology will be called hostile and revealed as Turk-lovers and enemies of Greece; and the appellation 'classicist' will acquire a pejorative connotation and be used to discredit scholars. Lewis claims that, while absurd for Greek and Classics, 'if for classicist we substitute "Orientalist", with the appropriate accompanying changes, this amusing fantasy becomes an alarming reality', ${ }^{10}$ and he launches into a lengthy and vituperative account of the anti-Orientalist critique given by Said's book, including 'its science fiction history and its lexical Humpty-Dumptyism'. ${ }^{11}$

I do not mention Lewis' essay here so as to attack it and defend Said's work against it. Orientalism provoked such a mass of responses that it would be impossible to discuss them all in the compass of a brief essay. Robert Young writes, 'Few books can have sustained let alone survived the veritable barrage of critiques that have been deployed against Orientalism over the years. ${ }^{12}$ What I would like to point out is how Lewis' fantasy scenario both confirms precisely one of the main arguments of the book and repeats a gesture made by many Hellenists. First, we see once again the Western intellectual's desire to forge a connection with classical Greece and thus to reaffirm its privileged though arbitrary position in the tradition. The analogy with classical scholarship, when made by this scholar of classical Islam and Arabia, appears to constitute Greece as an object of desire and to mask a sense of disciplinary inferiority. Second, a startling omission from Lewis' dreamscape, apart from brief and undeveloped allusions, is that of European colonialism and imperialism. Given that Orientalism only makes sense within the context of two hundred years of European rule and conquest of non-European peoples, this evasion and suppression fully deprive Said's claims of their 
socio-political context and in fact render them unintelligible. And thirdly, of course, Lewis' illusory example and his essay in general remain blind to the politics of knowledge, to the notion of colonial discourse, to the relationship between power and knowledge - in short, to the range of methodological issues raised by Orientalism. I have already considered, albeit briefly, the anxieties connected with maintaining Greece as a privileged, originary, and influential locus within Euro-American thought and culture. Let me now take up the other two aspects and relate them to Hellenism and the study of Greek antiquity.

To anyone reviewing the history of classical scholarship as it is written by its practitioners today, the most glaring lacuna in it remains the failure to explore the ramifications of a book already twenty-five years old and with direct relevance to the field. ${ }^{13}$ There is no developed history of classical scholarship that takes into account the intersection of the discipline with European colonialism and imperialism from the 1700s to the 1900s. For reasons that are of considerable interest, scholars seem to be unable or uninterested in exploring the collusion between Classics and empire, despite the indisputable evidence for such collusion. If Said's powerful demonstration of the relationship between Orientalist discourse and European colonial power seems not to have inspired similar work about the field of classics, within and without the discipline, then we are obliged to interrogate this resistance to the politics of Classical scholarship, and in particular to the coincidence between Classics and Empire. It is not enough to remark that Said's theory does not pertain to Greece on the grounds that no modern European power ever colonized Greece or even that Greece itself lies in Europe and not in Asia (in fact, the situation of Greece make the latter distinction exceedingly problematic). This sort of response tends to dismiss the colonial context of classical scholarship, which in any case was shaped decisively by imperial powers, and refuses to examine the continuing impact of the colonial past on Classics today. Said's work has been concerned with scholarship, philology, the production of knowledge, and imperial 
and colonial aggression in the eighteenth to the twentieth centuries. These factors are central, not peripheral, to the historical study of Greece as it is understood in our own time. Instead of avoiding the issues, we must ask, with figures such as Rey Chow, 'Why were questions of Orientalism not asked earlier, and why are they being avoided even now $?^{14}$ Classical scholars have used the two or three pages that Said devotes to Greek antiquity as a point of departure, and with this abstraction, they have more or less disregarded the location of these pages within the broader frame of modern European colonialism, thereby repeating the same gesture that Lewis makes in removing Orientalism from its political and historical context.

The project of reorienting Hellenism is, in fact, connected with the relatively recent critiques that have emerged from inside and outside the field, especially in relation to gender, race, and class, though the links between these activities are not always articulated clearly. Moreover, despite the effort and ingenuity behind these attempts to understand sexual, racial, and political configurations, and despite their meticulous research and scrupulous concern with method, very little of this work has further interrogated the collusion between Classics and empire. It may be that since Said does not directly engage either with classical scholarship or with German scholarship, Orientalism has not sparked a thorough or programmatic revaluation of European scholarship on ancient Greece and Rome. I do not wish to suggest that, for this reason alone, such work should be regarded as politically naive, historically false, or limited in its understanding of its institutional and discursive settings. Rather, it is more productively useful to see these projects as overlapping, in interest, method and scope, with a rigorous analysis of the entanglements between Classics and colonialism. For instance, the patriarchal dominance underpinning the study of Greek antiquity is well documented, and many projects have investigated the sexual and gender asymmetries both in the Greek past and in the study of antiquity. But we are only just beginning to understand the relationship between constructions of gender and sexuality in a modern 
colonial context, on the one hand, and similar categories in the ancient world, on the other. It will be exciting now to have an account, say, of how the British discourse of effeminacy that developed in colonial Bengal interacted with the contemporary British reception of Plato or Demosthenes. ${ }^{15}$ Again, the most famous work of our time about Greek antiquity, Martin Bernal's Black Athena, has radically transformed the nature and status of research about Classics in the nineteenth century. Bernal's emphasis on the frankly anti-Semitic and racist nature of the scholarship is a salutary reminder about the socio-political conditions in which knowledge is produced. Nevertheless, Bernal's focus remains heavily though not entirely on German scholarship; much of the work carried out in the past generation or so has been concerned largely with German scholarship and the formation of the discipline in Germany, which was nonetheless not a colonial power in the sense that Britain and France were. Hence, those who write about classical scholarship will need also to recognize the wider circle of knowledge in which discourses of modern racism takes their historical situation. In matters of class, such a survey as Classics Transformed, by Christopher Stray, offers a convenient opening into the institutional genealogy of Classics from 1830 onwards by virtue of its discussion of elite formation and social differentiation in England. ${ }^{16}$ But the additional consideration of imperialism and colonialism substantially extends its analysis of class and social hierarchies. Similarly, one might mention many other examples, from disparate perspectives, that potentially provide the basis for 'new objects of knowledge, new praxes of humanist activity, new theoretical models that upset or, at the very least, radically alter the prevailing paradigmatic norms'. ${ }^{17}$

In this regard, it is worth noting that Roman studies has found it easier to engage with its own worldly involvement than Hellenic studies, although the former, too, has not benefited from a truly profound appreciation of the socio-political conditions of its production. There may be various explanations for this discrepancy, including real differences between the ancient cultures. Perhaps, the ways in which Rome and Greece 
have entered modern European consciousness are responsible. Perhaps, the perceived contrast between the Roman Empire and Greek democracy is responsible for contributing to this kind of imbalance in the disciplinary history, which, unlike the Victorian tradition itself, disregards early Greek 'colonization' or the Athenian 'empire' or the fact that Thucydides posed the problem of how a state might be a democracy at home and an empire overseas. In Britain, at least, comparisons between the Roman and British empires date back to the aggressive phase of British imperialism in the late 1800s. Richard Hingley begins his book, Roman Officers and English Gentlemen, with a quotation from Said's Culture and Imperialism, a text which continues and extends the analyses presented in Orientalism. Hingley well demonstrates 'the use of Roman archaeology as imperial discourse - the ways in which the Roman past has been used in the definition of imperial purpose' ${ }^{18}$ Hingley's work was anticipated to some extent by writers such as Jane Webster, Nicholas Cooper, and Norman Vance, among others. ${ }^{19}$ Nevertheless, most if not all of this material focuses on the domestic political scene rather than the imperial contact zone overseas, and we are required to say that there is still a remarkably vast space for thorough, sustained, and developed critiques of the phenomenon. As far as Hellenism is concerned, the need for critique is even more pressing, as the few existing discussions suggest. ${ }^{20}$

I would like to illustrate the claims I am making with the help of an example drawn from a British context, namely, Oxford. For reasons of space, I shall not discuss here the subject of Hellenism and Empire in connection with countries such as France or Spain, the national traditions of which continue to show the influence of colonialism. Nor shall I dwell on the U.S.A., although analysis of the power-knowledge relationship in the United States remains an urgent task, not least because American imperialism continues to exert its power on a world-wide scale. In the nineteenth and early twentieth centuries, however, to say Oxford is already to invoke a much larger, more global, sphere of influence than the name of the university might suggest. From the colleges that have 
published records, it appears that approximately $20 \%$ of graduates went on to work in the British Empire outside of the UK. ${ }^{21}$ Most of these men read Classics at colleges such as Balliol, Keble, St John's, and Corpus Christi College. Their influence on such institutions as the Indian Civil Service is staggering to behold: 'in the period from 1892 to 1914 almost half the entrants to the ICS were Oxford graduates, with the consequence that by 1938 six out of eight provincial governors in India were Greats men who had taken their degrees between 1897 and $1910^{\prime} .^{22}$ Instrumental to this astounding act of imperialism was J. L. Strachan-Davidson, who was at Balliol College, first as tutor and later as Master. Among his books are Selections from Polybius (1888), which continued to be assigned as a text-book to Oxford students until as late as 1984, and Problems of Roman Criminal Law (1912). But even before Strachan-Davidson came Benjamin Jowett, who was head of the same college and no less influential in affecting the course of Empire. Today, Jowett is famous as a translator of Plato's dialogues, but in his day he canvassed hard to enable his Classics students to go far and wide throughout the Empire and to serve in such institutions as the Indian Civil Service. He used his position on Macaulay's Committee on the Indian Civil Service to make it easier for his students to secure places in the ICS, and he insisted that more than half the marks in the ICS examinations be weighted in favour of Greek and Latin. ${ }^{23}$ Jowett's model was Plato's Republic, which inspired him to think of his students as potential 'guardians' and to claim, in a letter to Florence Nightingale, that he wished 'to govern the world through my pupils'.$^{24}$ In addition to Strachan-Davidson and Jowett, scores of other Oxford classicists were involved in Empire. If the list of names were to include both teachers and students who read Greats, the roster would become impossibly long and distinguished. What is further interesting about Strachan-Davidson and Jowett, however, is that their service to Empire also shaped their teaching and writings about the ancient Greek world. Read Jowett's letters, read his committee reports, read his papers, and you see a committed attempt to work out nineteenth-century political problems through the classical Greek material. Just 
as ICS graduates went out to India and maintained imperial policy with a background informed by Classics, so also the presence and pressure of the Empire overseas exerted an impact on the study and transmission of Greek antiquity in Britain.

However, the example of Classics and Empire in the Oxford context also raises a quantity of other questions the appreciation of which would incomparably deepen our understanding of the imperial endeavour and the study of antiquity. Consider Jowett, for example. Three viceroys of India in succession were his former students. But for all the evidence he gives of being an imperialist, he was also dismayed by the racism of the British in India, and he encouraged Indian students to study in his college, which indeed came to have more Indian students than any other. ${ }^{25}$ These Indian students themselves returned to India, and put their Oxford education to work at home, within and outside the ICS. There are, thus, overlapping histories and experiences that emerge from the colonial encounter, as we learn also from the case of Gilbert Murray, the Regius Professor of Greek who, after Jowett, opposed aggressive imperialism and took the Liberal view on empire. ${ }^{26}$ Said has remarked, 'Many of us who grew up in the colonial era were struck by the fact that even though a hard and fast line separated coloniser from colonised in matters of rule and authority (a native could never aspire to the condition of the white man), the experiences of ruler and ruled were not so easily disentangled. On both sides of the imperial divide men and women shared experiences - though differently inflected experiences - through education, civic life, memory, war. ${ }^{27}$ This is not to deny the massive violence inflicted by the colonial empires over the lands and peoples whom they ruled, nor is it to undervalue the forces of native resistance that fought hard to overthrow colonial rule. No: instead, it is to account for the complexities of the phenomena, and to explain why a freedom-fighter such as M. K. Gandhi wrote his Hind Swaraj ("Indian Home Rule") of 1909 in the manner of a Platonic dialogue. ${ }^{28}$ A sensitive account of the colonial situation, then, would cover not only the stark power imbalances through which 
colonialism functioned, but also the 'shared experiences' of colonizer and colonized, in the manner that Said suggests.

In considering European colonialism, I have been looking at some of the methodological issues posed by Said's work, but I would like to close by making a point that has been implicit throughout the discussion. The failure to acknowledge the colonial genealogy of Classics is both the symptom and cause of a problem: on the one hand, the (academic and non-academic) discourse of ancient Greece and Rome is unable to come to grips with fundamental elements of its own problematic history of the last two hundred or so years; on the other hand, the colonial genealogy is itself responsible for the internal inability to question this history. Colonialism was assisted by the discourse of ancient Greece and Rome, but at the same time colonialism also facilitated the conditions in which it was possible for the discourse to emerge and flourish. As indicated above, European colonialism decisively changed the way in which Greek and Roman antiquity was conceptualized, understood, and taught in the nineteenth and twentieth centuries. This is not a history that those in the discipline narrate about themselves with any thoroughness or depth, however, and until there are many such analyses, Classics will continue to reproduce itself without any real acceptance of its own recent past. What matters is not that students of antiquity adopt new methods or theories casually, but that they genuinely think through what it means for them to profess and teach the past in the present historical moment, when the legacy of empire continues to do its work openly or in secret. The acknowledgement of the imperial experience in Europe and the U.S.A. has the potential radically to transform the very nature of the questions that are put to Classics and to the distant past as well to the recent colonial era.

If one of the goals of colonial studies is to bring about 'the dislocation of the modern West' ${ }^{29}$ Edward Said's work has surely made a major contribution to the enterprise, even if he has been far from alone in the effort. Thanks to the writings of colonial and postcolonial critics, we see that the modern West has constructed itself 
retroactively so as to separate itself from an Orient, which it nonetheless seems incapable of casting out entirely. The myths of Europe include the founding myth that authoritatively and programmatically traces its antecedents all the way back to distant Hellas. But the epistemological critiques instigated by colonial studies have fragmented such a meta-narrative; and in its place, we find local histories with plural objects and a proliferation of discrete activities that thrive on the recognition of difference. Now that Europe's self-representation seems crossed from within by the 'Orient', now that Europe itself has been 'provincialized', ${ }^{30}$ neither ancient Greece nor the study of ancient Greece can be thought of as they were by many scholars even twenty-five years ago. Indeed, the lesson we take from Orientalism is that how, what, and even why any one today thinks about ancient Greece is inseparable from two hundred years of European colonialism. Within the field of Hellenic studies, the awareness of this lesson is only just beginning to have an impact, as the background of those who teach and study Classics in Europe and the U.S.A. becomes more diverse. An Egyptian, Iranian, or Indian is going to respond very differently to Herodotus than a white European who has been raised in the AngloSaxon tradition. 'To write well about colonialism,' Said notes, 'you don't have to have had a colonial or imperialist background, but as with any history of a complex experience that involved many actors, the worst thing - even in the name of critical impartiality - is to empty that history of its existential residue in the present. . . ${ }^{31}$ Whatever the backgrounds of those who are trying to forge inclusive histories of Hellenism, such projects not only will lead to accounts of ancient Greece and its reception through the ages that are more open and less totalizing; they also will give us the ability to understand and to transform the imperial present in which we now live. 
${ }^{1}$ Edward W. Said, Orientalism (New York: Pantheon Books, 1978), p. 3.

${ }^{2}$ Said, Orientalism, p. 56.

${ }^{3}$ Said, Orientalism, p. 57.

${ }^{4}$ Edith Hall, Inventing the Barbarian: Greek Self-Definition through Tragedy (Oxford: Clarendon Press, 1989), p. 99.

${ }^{5}$ See e.g. the nine volumes of Achaemenid History, edited by Heleen SancisiWeerdenburg et al. (Leiden, 1988-1998); Sarah P. Morris, Daidalos and the Origins of Greek Art (Princeton: Princeton University Press, 1992); Phiroze Vasunia, The Gift of the Nile: Hellenizing Egypt from Aeschylus to Alexander (Berkeley: University of California Press, 2001).

${ }^{6}$ Julius Jüthner, Hellenen und Barbaren aus der Geschichte des Nationalbewusstseins (Leipzig: Dieterich, 1923); Walther Kranz, Stasimon: Untersuchungen zu Form und Gehalt der griechischen Tragödie (Berlin: Weidmann, 1933); Arnaldo Momigliano, Alien Wisdom: The Limits of Hellenization (Cambridge: Cambridge University Press, 1975; repr. 1978).

${ }^{7}$ Martin Bernal, Black Athena: The Afroasiatic Roots of Classical Civilization, vol. 1: The Fabrication of Ancient Greece, 1785-1985 (New Brunswick: Rutgers University Press, 1987) and vol. 2: The Archaeological and Documentary Evidence (New Brunswick: Rutgers University Press, 1991); Walter Burkert, The Orientalizing Revolution: Near Eastern Influence on Greek Culture in the Early Archaic Age, trans. Margaret E. Pinder and Walter Burkert (Cambridge, Mass., and London: Harvard University Press, 1992); M. L. West, The East Face of Helicon: West Asiatic Elements in Greek Poetry and Myth (Oxford: Clarendon Press, 1997). 
${ }^{8}$ Stathis Gourgouris, Dream Nation: Enlightenment, Colonization, and the Institution of Modern Greece (Stanford: Stanford University Press, 1996), p. 140.

${ }^{9}$ Bernard Lewis, 'The Question of Orientalism', in Islam and the West (New York and Oxford: Oxford University Press, 1993), p. 99. The essay was first published in The New York Review of Books (24 June 1982), pp. 49-56.

${ }^{10}$ Lewis, Islam and the West, p. 100.

${ }^{11}$ Lewis, Islam and the West, p. 114

${ }^{12}$ Robert J. C. Young, Postcolonialism: An Historical Introduction (Oxford: Blackwell Publishers, 2001), p. 384.

${ }^{13}$ See Stefan Hauser, 'Orientalismus', in Manfred Landfester, with Hubert Cancik and Helmuth Schneider (eds.), Der Neue Pauly: Enzyklopädie der Antike, vol. 15/1: Rezeptions- und Wissenschaftsgeschichte (Stuttgart and Weimar: Verlag J. B. Metzler, 2001), pp. 1234-43.

${ }^{14}$ Rey Chow, Writing Diaspora: Tactics of Intervention in Contemporary Cultural Studies (Bloomington and Indianapolis: Indiana University Press, 1993), p. 10.

${ }^{15}$ Linda Dowling, Hellenism and Homosexuality in Victorian Oxford (Ithaca and London: Cornell University Press, 1994); Mrinalini Sinha, Colonial Masculinity: The 'Manly Englishman' and the 'Effeminate Bengali' in the Late Nineteenth Century (Manchester: Manchester University Press, 1995).

${ }^{16}$ Christopher Stray, Classics Transformed: Schools, Universities, and Society in England, 1830-1960 (Oxford: Clarendon Press, 1998).

${ }^{17}$ Edward W. Said, 'Orientalism Reconsidered', Race \& Class 27, 2 (1985), p. 13. 
${ }^{18}$ Richard Hingley, Roman Officers and English Gentlemen: The Imperial Origins of Roman Archaeology (London and New York: Routledge, 2000), p. 164. And see Edward W. Said, Culture and Imperialism (New York: Knopf, 1993).

${ }^{19}$ Jane Webster and Nicholas J. Cooper (eds.), Roman Imperialism: Post-Colonial Perspectives. Proceedings of a Symposium held at Leicester University in November 1994. Leicester Archaeology Monographs No. 3 (Leicester: Leicester University Press, 1996); Norman Vance, The Victorians and Ancient Rome (Oxford: Blackwell Publishers, 1997); and cf. Frank M. Turner, Contesting Cultural Authority: Essays in Victorian Intellectual Life (Cambridge: Cambridge University Press, 1993).

${ }^{20}$ See e.g. Richard Jenkyns, The Victorians and Ancient Greece (Cambridge, Mass.: Harvard University Press, 1980), ch. 13; Suzanne L. Marchand, Down from Olympus: Archaeology and Philhellenism in Germany, 1750-1970 (Princeton: Princeton University Press, 1996); Franco De Angelis, 'Ancient Past, Imperial Present: The British Empire in T. J. Dunbabin's The Western Greeks', Antiquity 72 (1998), pp. 539-49.

${ }^{21}$ Richard Symonds, Oxford and Empire: The Last Lost Cause?, corr. edn. (Oxford: Clarendon Press, 1991), p. 306.

${ }^{22}$ Oswyn Murray, 'Ancient History, 1872-1914', in M. G. Brock and M. C. Curthoys (eds.), The History of the University of Oxford, vol. VII: Nineteenth-Century Oxford, Part 2 (Oxford: Clarendon Press, 2000), p. 346.

${ }^{23}$ Javed Majeed, 'Comparativism and References to Rome in British Imperial Attitudes to India', in Catharine Edwards (ed.), Roman Presences: Receptions of Rome in European Culture, 1789-1945 (Cambridge: Cambridge University Press, 1999), pp. 88-109.

${ }^{24}$ Quoted in Symonds, Oxford and Empire, p. 24.

${ }^{25}$ Symonds, Oxford and Empire, p. 28. 
${ }^{26}$ See Francis W. Hirst, Gilbert Murray, and John L. Hammond, Liberalism and the Empire: Three Essays (London: R. Brimley Johnson, 1900; repr., London:

Routledge/Thoemmes Press, 1998); and the biography by Duncan Wilson, Gilbert Murray, OM. 1866-1957 (Oxford: Clarendon Press, 1987).

${ }^{27}$ Edward Said, 'Always on Top', London Review of Books 25, 6 (20 March 2003), p. 3.

${ }^{28}$ M. K. Gandhi, Hind Swaraj and Other Writings, ed. Anthony J. Parel (Cambridge: Cambridge University Press, 1997).

${ }^{29}$ Gyan Prakash, 'Orientalism Now', History and Theory 34, 3 (1995), p. 000.

${ }^{30}$ Dipesh Chakrabarty, Provincializing Europe: Postcolonial Thought and Historical Difference (Princeton and Oxford: Princeton University Press, 2000).

${ }^{31}$ Said, 'Always on Top', p. 5. 